\title{
Stem cells in tissue engineering - dynamic cultivation requirement
}

\author{
Dijana Trišić1, Vukoman Jokanovićc ${ }^{2}$ Đorđe Antonijevićc,3, Dejan Marković1 \\ ${ }^{1}$ University of Belgrade, Faculty of Dental Medicine, Clinic for Pediatric and Preventive Dentistry, Belgrade, Serbia; \\ ${ }^{2}$ University of Belgrade, Vinca Institute of Nuclear Sciences, Department of Atomic Physics, Belgrade, Serbia; \\ ${ }^{3}$ University of Belgrade, Institute of Anatomy, Faculty of Medicine, Laboratory for Anthropology, Belgrade, Serbia
}

\begin{abstract}
SUMMARY
Stem cells have shown great potential for in vitro tissue engineering, regenerative medicine, cell therapy and pharmaceutical applications. All these applications, especially in clinical trials, will require guided production of high-quality cells. Traditional culture techniques and applications have been performed for the majority of primary and established cell lines and standardized for various analyses. Still, these culture conditions are unable to mimic dynamic and specialized three-dimensional microenvironment of the stem cells' niche from in vivo conditions. In an attempt to provide biomimetic microenvironments for stem cells in vitro growth, three-dimensional culture techniques have been developed. In our study advantages of newly developed porous scaffolds as the most promising in vitro imitation of niche that provides physical support, enables cell growth, regeneration and neovascularization, while they are replaced in time with newly created tissue was explained. Furthermore, dynamic cultivation techniques have been described, as new way of cell culturing that will be the main subject of our future research. In that manner, by developing an optimal dynamic culturing method, high-quality new cells and tissues would be possible to obtain, for any future clinical application. Keywords: stem cells; culture technique; scaffolds; ALBO-OS; bioreactor
\end{abstract}

\section{INTRODUCTION}

Stem cells (SCs) have the ability to self-renew and differentiate into mature types of cells that develop all organs and tissues in human body. There are two major categories of SCs defined by their origin and potency - embryonic stem cells, and adult, mesenchymal stem cells [1]. Embryonic stem cells (ESCs) are pluripotent, capable of unlimited self-renewal and differentiation into any type of cell in the body. Mesenchymal stem cells (MSCs) are isolated from adult sources such as bone marrow, adipose, and dental tissue. MSCs are multipotent cells that can differentiate into a limited number of cell types. Also, self-renewal and differentiation potential is dependent on the tissue they are isolated from, and age of a donor. The advantages are accessibility and less ethical concerns for their usage [2,3].SCs have shown great potential for in $v i$ tro tissue engineering, regenerative medicine, cell therapy and pharmaceutical applications. All these applications, especially in clinical trials, will require a guided production of high-quality cells [4].

\section{TRADITIONAL CULTURE TECHNIQUES}

SCs are propagated as a monolayer in two-dimensional (2-D) plastic culture plates. 2-D culture techniques and applications have been practiced for the majority of pri- mary and established cell lines and standardized for various analyses, from isolation and characterization of cells, to the studies of diseases development and drug testing [5]. To grow cells on plastic culture dishes, ESCs have to be seeded on precoated surface to aid in attachment. 2-D expansion of ESCs has been improved by applying defined and xenogenic-free culture media and attachment substrates. However, uniform expansion of ESCs is still difficult to achieve as 2-D culture methods for propagation of ESCs are challenging, expensive and require high level of expertise [5,6]. Differentiation of ESCs has been achieved by using specific induction media into ectodermal, mesodermal, and endodermal lineages. An important advantage of monolayer culture is controlled differentiation of human ESCs that allows uniform treatment for differentiation of cells. However, differentiation in monolayer culture often results in mixed populations of differentiated cells $[4,5,7]$.

Unlike embryonal, MSCs have natural ability to adhere to plastic and glass surfaces. Xenogenic substrates are not necessitated for attachment, although they are usually cultured in the media containing animal serum. Use of animal-derived media can potentially transmit pathogens and limit reproducibility between cultures. Recently, xenogenic-free media has become available for cultivation of MSCs [8]. Expansion of MSCs in monolayer has its limitations. Monolayer culture needs routine passaging to maintain self-renewal and potency of cells, which is 
highly inefficient for large-scale expansion of cells. Maintenance of uniform distribution, growth, and harvesting processes is needed and consequently, heterogeneity is minimized and cell yield is high. Phenotypic changes occur in MSCs while culturing in monolayers, and cells' fate and differentiation potential are altered after numerous passages [9]. Despite the limitations, 2-D culture has been used for differentiation of MSCs into many specialized cells, including chondrocytes, osteocytes, adipocytes, cardiomyocytes, smooth muscle cells, and hepatocytes, by using cell-specific differentiation media [10,11]. Assessment of differentiation stages is commonly done by specific transcriptional gene expression and extracellular matrix (ECM) depositions. The main downside of monolayer differentiation is a lack of providing functionally competent cells. They often differentiate into precursor-like cells, suggesting the possibility to re-differentiate during extended culturing [4]. Prior to clinical application, modification of differentiation protocols should be made. Overall, 2-D culture conditions are unable to mimic dynamic and specialized three-dimensional (3-D) microenvironment of the SC niche from in vivo conditions.

\section{THREE-DIMENSIONAL CULTURE TECHNIQUES}

In an attempt to provide biomimetic microenvironments for stem cells in vitro growth, 3-D culture techniques have been developed. These methods have a common goal to mimic the ECM composition and stiffness of SC niche in vitro. Challenge lies in protocol optimization depending on cell type and the aim of analysis [4]. Therefore, the uniform expansion of SCs without loss of genetic stability or differentiation potential has to remain regardless of applied technique.

\section{Static three-dimensional culture}

\section{Spheroids}

Formation of spheroids that consist of cell aggregates and allow cell interactions in the absence of additional substrates is one of the simplest 3-D culturing method. A wide range of adherent cell types have the ability to form spheroids by spontaneous cell aggregation when they are seeded in low-adhesion culture plates in suspension culture, in a form of a hanging drop, or in rotating culture [7, 12]. MSCs are successfully maintained and expanded by spheroid method where they exhibited increased clonal growth and multipotency, and activation of pluripotency genes. However, as in monolayer cultivation, long-term culture of MSCs in spheroids spontaneously led to differentiation [12]. In comparison with monolayer culture, MSCs grown in 3-D spheroids have shown increased chondrogenic and osteogenic differentiation in vitro. In particular, chondrogenic differentiation of MSCs has been shown as more effective in high-density cell culture methods utilizing pellet culture or spheroids, in comparison to 2-D culture. Still, this method is not applicable for cell expansion due to the inability to control aggregate size, leading to agglomeration, apoptosis, and inhibition of cell proliferation [13]. Depending on tissue that cells are isolated from, spheroids could consist of heterogeneous population of cells, with different proliferative capacity. Even more important drawback is limited diffusion of oxygen and nutrients in the center of the spheroid, which gradually leads to a hypoxic environment, and at the end, formation of necrotic center. Due to these drawbacks, spheroids have been more successfully employed in study of 3-D cell structures, cell differentiation and cancer biology rather than homogenous cell proliferation and production of high-quality uniform cell cultures $[13,14]$.

\section{Scaffolds}

Various natural and synthetic biocompatible and biodegradable materials have been used to mimic the biochemical and biophysical properties of SC niches that stimulates cell proliferation and/or differentiation. Natural biomaterials (agarose, fibronectin, hyaluronic acid, chitosan) in vitro often transduce biological signals to cells [15]. As a result, biomaterials can aid in cell maintenance and differentiation. However, problems such as variability and the potential of xenogenic media components to cause disease limit their use $[15,16]$. Synthetic polymers (polyethylene glycol, poly-l-lysine, poly-lactic acid, polyglycolic acid, and poly-dl-lactic acid-co-glycolic acid) are the group of artificially made scaffolds with different mechanical properties (pore size, elasticity, adhesion, tensile strength) [17-22]. Biodegradable, porous scaffolds represent the most promising in vitro imitation of SC niche that provides physical support, enables cell growth, regeneration and neovascularization, while they were replaced in time with new bone [23, 24, 25]. Innovative scaffold construction that consists of ceramic part mimicking bone structure, and thin polymer layer above that contribute its' better mechanical properties and biocompatibility, showed to be very promising biomaterial for bone tissue engineering (Figure 1) [21, 25, 26]. Scaffolds are commonly used as carriers that mimic ECM, promote expansion, migration, and differentiation of SC. For SC culturing, scaffolds can be prefabricated, afterward, cells are seeded onto the scaffold, and allowed to migrate and proliferate $[20,27,28]$. Scaffolds can incorporate growth factors and cytokines, and provide mechanical stimulation for SC differentiation. On the other side, there are scaffolds with self-assemble encapsulating cells that are incorporated in biomaterial at the time of its fabrication. Due to these advantages, prefabricated scaffolds are commonly used for seeding SCs prior to their differentiation and usage in tissue engineering [28]. We recently reported successful application of composite scaffold, combination of calcium hydroxyapatite and poly (lactic-co-glycolic) acid, named ALBO-OS, as a bone substitute $[21,25]$. Scaffold with very high porosity and nanotopology showed to be very suitable for cell adhesion and proliferation (Figure 2), providing larger surface area, allowed better adhesion and provided more area for differentiation of MSCs [24]. Furthermore, it has been shown the formation of new mineralized matrix, osteoconductive and certain 


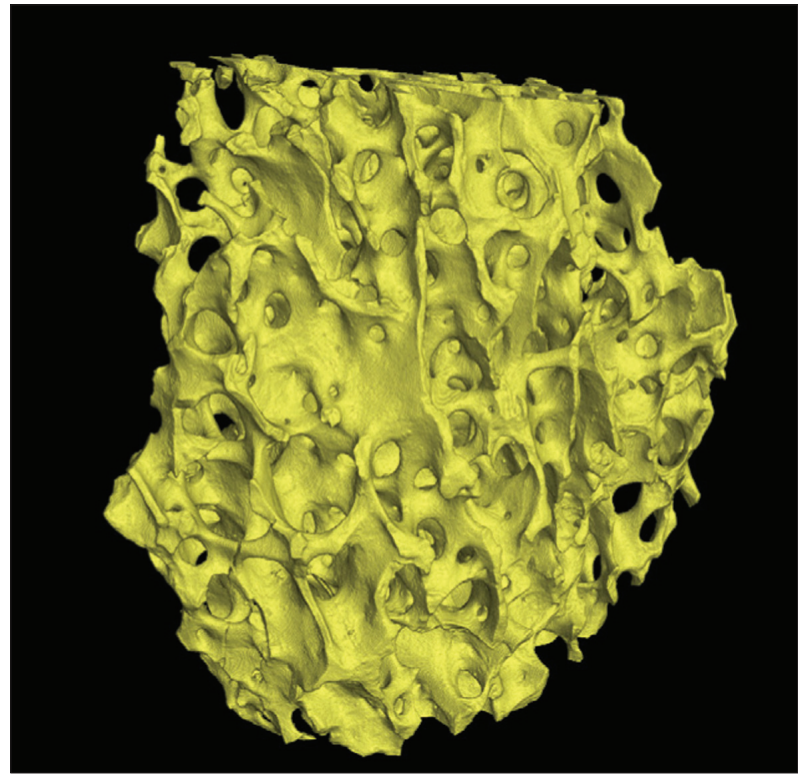

Figure 1. Micro CT volume reconstruction of ALBO-OS carrier; porous biomaterial has ideal micro- and nano-porosity, trabecular thickness, cylindrical shape of the pores, pore diameter and connectivity of bone scaffold model

Slika 1. Mikro CT zapreminska rekonstrukcija ALBO-OS nosača, poroznog biomaterijala idealne mikro i nanoporoznosti, debljine trabekula, pora cilindričnog oblika, dijametra i međusobne povezanosti modela koštanog zamenika

osteoinductive effect (Figure 3). Compressive strength of ALBO-OS showed to be a good mechanical support during the whole period of its transformation into new bone $[21,24,25]$.

It has been shown that scaffold mechanical properties stimulate differentiation of MSCs into various lineages. Softer substrates induced MSC differentiation into neural and beta islet cells, chondrocytes and adipocytes. On the other hand, increase in substrate stiffness supported MSC differentiation into myoblasts and osteoblasts. Compres-

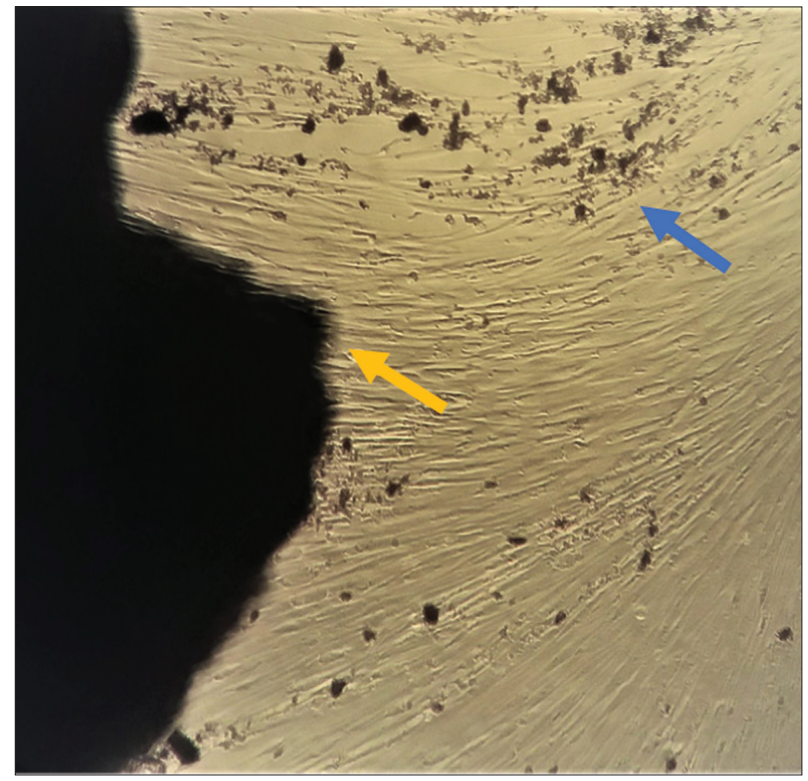

Figure 2. Stem cells from apical papilla (SCAP), from $5^{\text {th }}$ passage, after 5 days of cell culture seeded on ALBO-OS carrier. Yellow arrow points tight contact of scaffold and confluent SCAP; blue arrow points scaffold particles released in growth medium during culturing covering SCAP.

Inverted microscope, 100x

Slika 2. Matične ćelije poreklom iz apikalne papile (SCAP), iz pete pasaže, posle pet dana gajenja ćelija na ALBO-OS nosaču. Žuta strelica pokazuje na bliski kontakt nosača i gusto naseljenih SCAP; plava strelica pokazuje sitne delove nosača oslobođene u hranljivom medijumu koje prekrivaju SCAP.

Invertni mikroskop, 100x

sive forces mimicking joint action via mechanotransductive scaffold increased chondrogenic gene expression in MSCs [27, 28]. Since the composition and mechanical properties of biomaterials guide MSCs differentiation into specific cell lineages, it is important to be optimised and easily producible. Cell-cell and cell-ECM interactions in static 3-D culture during maintenance and expansion of
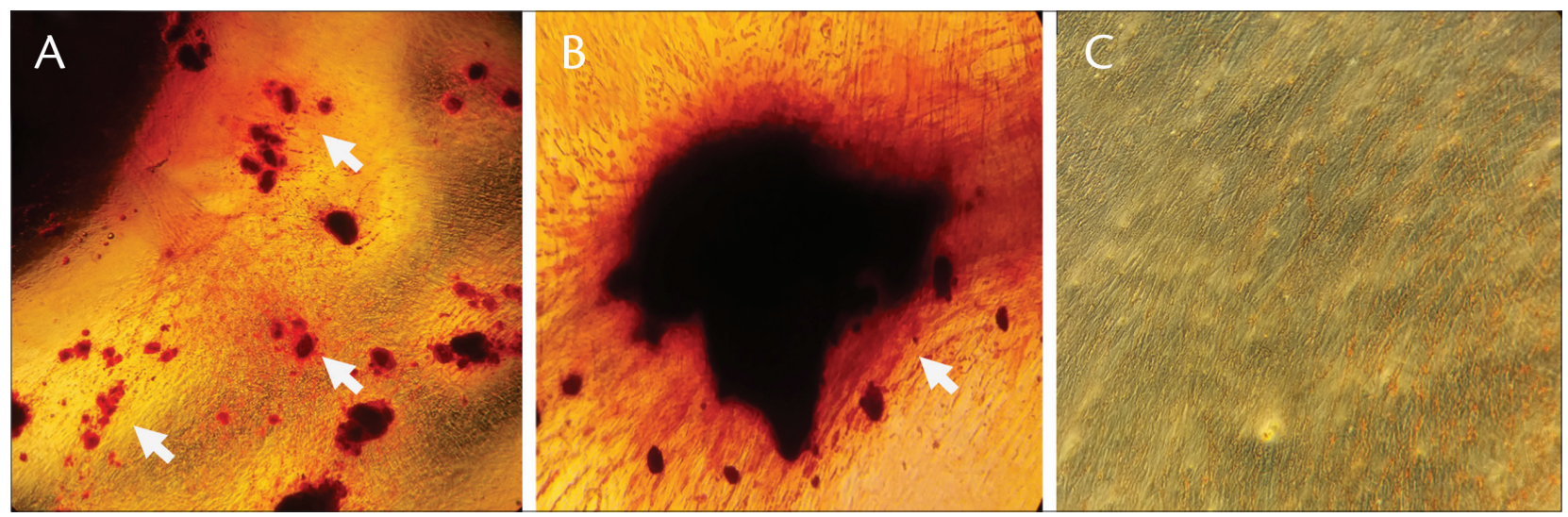

Figure 3. Alizarin Red $S$ staining after 21 days of SCAP seeded on ALBO-OS carrier in growth medium ( $A$ and B), and SCAP in growth medium as a control (C). White arrows point on numerous calcium deposits in the red colored complex of newly deposited mineralized extracellular matrix, suggesting significant osteoinductive potential of ALBO-OS. In control no mineralization was observed except some spontaneous mineralized nodules.

Inverted microscope, $40 \times(A), 100 \times(B, C)$.

Slika 3. Bojenje SCAP Alizarin crvenim nakon 21 dana gajenja ćelija na ALBO-OS nosaču u hranljivom medijumu (A i B), i samih SCAP gajenih u hranljivom medijumu kao kontrolna grupa (C). Bele strelice pokazuju na brojne kalcijumske nakupine obojene crvenom bojom u kompleksu novostvorenog mineralizovanog vanćelijskog matriksa, ukazujući na značajan osteoinduktivni potencijal ALBO-OS nosača. U kontroli mineralizacija nije uočena, osim pojedinačnih spontano mineralizovanih čvorića. Invertni mikroskop, $40 \times(A), 100 \times(B, C)$. 
MSCs can provide insight on basic cell biology processes and mechanisms. The main challenge of 3-D static cultivation remains extensive cell expansion in individual scaffold constructs. By increasing in size of scaffold, cell growth in the center could be compromised in a similar way as in spheroids. Flow of oxygen, nutrients, and waste in whole scaffold space might be limited [4]. Methods that could provide 3-D cell growth and expansion without nutritional drawbacks are the subject of current investigations.

\section{Dynamic three-dimensional culture}

Bioreactors are used to enable, monitor, and control biological processes. In tissue engineering, they enable culturing high densities of cells, allow cell growth and proliferation, and minimise variability observed in traditional culturing. The new way of cell culturing requires defined and well-regulated conditions regarding temperature, oxygen and nutrients concentration, $\mathrm{pH}$, as well as metabolites removal. Various types of 3-D culture techniques provide effective cell proliferation and differentiation [29]. There are differences in techniques used to develop bioreactor systems that affect their application.

Several bioreactor designs have been developed during recent years that can be used for expansion and guided differentiation from a single cell to tissue culture. Spinner flasks are one of the simplest and most convenient bioreactor systems. They operate by using local hydrodynamic forces that create shear stress on cells. In the center of the system is cell/scaffold assemble, while magnetic bar provides a constant flow of medium around scaffold. The system is placed in an incubator with controlled conditions. The degree of shear stress is defined by stirring speed. The downsides represent possibility of dense layer formation of cells on surface that could compromise nutrition of cells in the center, and unequal shear stress, with the highest level at the bottom of the flask [30]. Rotating bioreactors were designed for improved control of shear stress by horizontal rotation and simulation of microgravity. In this way limitations regarding the equal flow of nutrients and waste products are reduced [31]. The awareness of limitations of diffusion systems based on rotation led to development of perfusion bioreactors. Flow perfusion systems allow constant exchange of nutrients and waste, providing better control of culture parameters. They enable transport of nutrients and oxygen through the entire scaffold, while media must be changed at regular intervals [32]. Lastly, mechanical force bioreactors have been developed to mimic tissue physiology, by using direct mechanical strain such as compressive and tensile forces. Mechanical stimulation could be in the form of bending, stretching, contraction and compression. It has been shown that direct mechanical stimulation induced proliferation, osteogenic differentiation, and formation of ECM. A drawback could be diffusional limitations in larger constructs [33].

Future prospective research should include culturing of MSCs on porous scaffolds as promising tool for cells expansion and differentiation, in dynamic constructions, as flow perfusion systems, that would provide homogenous culturing conditions. In that manner, high-quality new cells and tissues would be possible to obtain regardless of scaffold size, which represents qualitative foundation for any clinical research.

\section{CONCLUSION}

Biomedical applications of stem cells require production of high number of uniform cells that nowadays well exceed millions of cells produced by traditional culturing techniques. Recent studies have shown that transplantation of higher cell concentration had better outcome. Billions to trillions of cells will be required in clinical trials involving cell therapy. Advancements in the developing xenogenic-free media, culturing techniques and devices are of great importance. Large scale of cell culturing demands collaboration between biomedical researchers and engineers, to develop an optimal dynamic culturing method that will provide therapeutic use of stem cells.

\section{REFERENCES}

1. Thomson JA, Itskovitz-Eldor J, Shapiro SS, Waknitz MA, Swiergiel JJ, Marshall VS, et al. Embryonic stem cell lines derived from human blastocysts. Science. 1998; 282(5391):1145-7.

[DOI: 10.1126/science.282.5391.1145] [PMID: 9804556]

2. Chen KG, Mallon BS, McKay RD, Robey PG. Human pluripotent stem cell culture: considerations for maintenance, expansion, and therapeutics. Cell Stem Cell. 2014; 14(1):13-26.

[DOI: 10.1016/j.stem.2013.12.005] [PMID: 24388173]

3. Ćetenović B, Čolović B, Vasilijić S, Pašalić S, Jokanović V, Marković D. In Vitro Biocompatibility of Nanostructured Endodontic Materials Using SCAP Cells. Balk J Dent Med. 2017; 21(3):167-70. [DOl: 10.1515/bjdm-2017-0029]

4. Mckee C, Chaudhry GR. Advances and challenges in stem cell culture. Colloids Surf B Biointerfaces. 2017; 159:62-77.

[DOI: 10.1016/j.colsurfb.2017.07.051] [PMID: 28780462]

5. Burdick JA, Vunjak-Novakovic G. Engineered microenvironments for controlled stem cell differentiation. Tissue Eng Part A. 2009; 15(2):205-19. [DOI: 10.1089/ten.tea.2008.0131] [PMID: 18694293]

6. Guilak F, Cohen DM, Estes BT, Gimble JM, Liedtke W, Chen CS Control of stem cell fate by physical interactions with the extracellular matrix. Cell Stem Cell. 2009; 5(1):17-26. [DOI: 10.1016/j.stem.2009.06.016] [PMID: 19570510]

7. Pineda ET, Nerem RM, Ahsan T. Differentiation patterns of embryonic stem cells in two- versus three-dimensional culture. Cells Tissues Organs. 2013; 197(5):399-410. [DOI: 10.1159/000346166] [PMID: 23406658]

8. Santos Fd, Andrade PZ, Abecasis MM, Gimble JM, Chase LG, Campbell AM, et al. Toward a clinical-grade expansion of mesenchymal stem cells from human sources: a microcarrier-based culture system under xeno-free conditions. Tissue Eng Part C Methods. 2011; 17(12):1201-10. [DOI: 10.1089/ten.tec.2011.0255] [PMID: 21895491]

9. Hanley PJ, Mei Z, da Graca Cabreira-Hansen M, Klis M, Li W, Zhao $Y$, et al. Manufacturing mesenchymal stromal cells for phase I clinical trials. Cytotherapy. 2013; 15(4):416-22. [DOI: 10.1016/j.jcyt.2012.09.007] [PMID: 23480951]

10. Friedenstein AJ, Chailakhyan RK, Latsinik NV, Panasyuk AF, KeilissBorok IV. Stromal cells responsible for transferring the microenvironment of the hemopoietic tissues. Cloning in vitro and retransplantation in vivo. Transplantation. 1974; 17(4):331-40. [PMID: 4150881]

11. Erickson GR, Gimble JM, Franklin DM, Rice HE, Awad H, Guilak F. Chondrogenic potential of adipose tissue-derived stromal 
cells in vitro and in vivo. Biochem Biophys Res Commun. 2002; 290(2):763-9. [DOI: 10.1006/bbrc.2001.6270] [PMID: 11785965]

12. Baraniak PR, McDevitt TC. Scaffold-free culture of mesenchymal stem cell spheroids in suspension preserves multilineage potential. Cell Tissue Res. 2012; 347(3):701-11. [DOI: 10.1007/s00441-011-1215-5] [PMID: 21833761]

13. Edmondson R, Broglie J), Adcock AF, Yang L. Three-dimensional cell culture systems and their applications in drug discovery and cellbased biosensors. Assay Drug Dev Technol. 2014; 12(4):207-18. [DOI: 10.1089/adt.2014.573] [PMID: 24831787]

14. Bartosh TJ, Ylöstalo JH, Mohammadipoor A, Bazhanov N, Coble K, Claypool K, et al. Aggregation of human mesenchymal stromal cells (MSCs) into 3D spheroids enhances their antiinflammatory properties. Proc Natl Acad Sci U S A. 2010; 107(31):13724-9. [DOI: 10.1073/pnas.1008117107] [PMID: 20643923]

15. Kraehenbuehl TP, Langer R, Ferreira LS. Three-dimensional biomaterials for the study of human pluripotent stem cells. Nat Methods. 2011; 8(9):731-6. [DOI: 10.1038/nmeth.1671] [PMID: 21878920]

16. Allen AB, Priddy LB, Li MT, Guldberg RE. Functional augmentation of naturally-derived materials for tissue regeneration. Ann Biomed Eng. 2015; 43(3):555-67. [DOl: 10.1007/s10439-014-1192-4] [PMID: 25422160]

17. Petrović M, Čolović B, Jokanović V, Marković D. Self assembly of biomimetic hydroxyapatite on the surface of different polymer thin films. J Ceram Process Res. 2012; 13:398-404.

18. Čolović B, Marković D, Petrović M, Jokanović V. Two-step hydrothermal synthesis of nanohydroxyapatite particles and their characterization. Journal of Optoelectronics and Advanced Materials. 2014; 16:1356-60

19. Jokanović V, Izvonar D, Dramićanin M, Jokanović B, Živojinović V, Marković D, et al. Hydrothermal synthesis and nanostructure of carbonated calcium hydroxyapatite. J Mater Sci Mater Med. 2006; 17:539-46. [DOI: 10.1007/s10856-006-8937-z] [PMID: 16691352]

20. Krishna L, Dhamodaran K, Jayadev C, Chatterjee K, Shetty R, Khora SS, et al. Nanostructured scaffold as a determinant of stem cell fate. Stem Cell Res Ther. 2016; 7(1):188. [DOI: 10.1186/s13287-016-0440-y] [PMID: 28038681]

21. Jokanović V, Čolović B, Marković D, Petrović M, Soldatović I, Antonijević $Đ$, et al. Extraordinary biological properties of a new calcium hydroxyapatite/poly(lactide-co-glycolide)-based scaffold confirmed by in vivo investigation. Biomed Tech (Berl). 2017; 62(3):295-306. [DOI: 10.1515/bmt-2015-0164] [PMID: 27285125]

22. Opačić-Galić $\vee$, Petrović $\vee$, Jokanović $\vee$, Živković S. Histological evaluation of tissue reactions to newly synthetized calcium silicate- and hydroxyapatite based bioactive materials - In vivo study. Srp Arh Celok Lek. 2017; 145(7-8):370-7. [DOI: 10.2298/SARH160719063O]
23. Jokanović V, Jokanović B, Marković D, Živojinović V, Pašalić S, Izvonar D, et al. Kinetics and sintering mechanisms of hydro-thermally obtained hydroxyapatite. Mater Chem Phys 2008; 111:180-5. [DOI: 10.1016/.j.matchemphys.2008.04.005]

24. Karadžić I, Vučić V, Jokanović V, Debeljak-Martačić J, Marković D, Petrović S, et al. Effects of novel hydroxyapatite-based 3D biomaterials on proliferation and osteoblastic differentiation of mesenchymal stem cells. J Biomed Mater Res A. 2015; 103(1):350-7.

25. Jokanović V, Čolović B, Marković D, Petrović M, Jokanović M, Milosavljević P, et al. In Vivo Investigation of ALBO-OS Scaffold Based on Hydroxyapatite and PLGA. I Nanomater. 2016; 2016:3948768. [DOI: 10.1155/2016/3948768]

26. Marković D, Karadžić I, Jokanović V, Vuković A, Vučić V. Biological Aspects of Application of Nanomaterials in Tissue Engineering. Chem Ind Chem Eng Q. 2016; 22(2):145-53.

[DOI: 10.2298/CICEQ141231028M]

27. Bian L, Zhai DY, Zhang EC, Mauck RL, Burdick JA. Dynamic compressive loading enhances cartilage matrix synthesis and distribution and suppresses hypertrophy in hMSC-laden hyaluronic acid hydrogels. Tissue Eng Part A. 2012; 18(7-8):715-24. [DOI: 10.1089/ten.TEA.2011.0455] [PMID: 21988555]

28. Haycock JW. 3D cell culture: a review of current approaches and techniques. Methods Mol Biol. 2011; 695:1-15. [DOI: 10.1007/978-1-60761-984-0_1] [PMID: 21042962]

29. King JA, Miller WM. Bioreactor development for stem cell expansion and controlled differentiation. Curr Opin Chem Biol. 2007; 11(4):394-8. [DOI: 10.1016/j.cbpa.2007.05.034] [PMID: 17656148]

30. Ismadi MZ, Gupta P, Fouras A, Verma P, Jadhav S, Bellare J, et al. Flow characterization of a spinner flask for induced pluripotent stem cell culture application. PLoS One. 2014; 9(10):e106493. [DOI: 10.1371/journal.pone.0106493] [PMID: 25279733]

31. Mazzoleni G, Di Lorenzo D, Steimberg N. Modelling tissues in 3D: the next future of pharmaco-toxicology and food research? Genes Nutr. 2009; 4(1):13-22.

32. Alvarez-Barreto JF, Linehan SM, Shambaugh RL, Sikavitsas VI. Flow perfusion improves seeding of tissue engineering scaffolds with different architectures. Ann Biomed Eng. 2007; 35(3):429-42. [DOI: 10.1007/s10439-006-9244-z] [PMID: 17216348]

33. Martin I, Wendt D, Heberer M. The role of bioreactors in tissue engineering. Trends Biotechnol. 2004; 22(2):80-6. [DOl: 10.1016/j.tibtech.2003.12.001] [PMID: 14757042] 


\title{
Matične ćelije u tkivnom inženjerstvu - potreba za dinamičnom kultivacijom
}

\author{
Dijana Trišić1, Vukoman Jokanović², Đorđe Antonijevićc,3, Dejan Marković \\ 'Univerzitet u Beogradu, Stomatološki fakultet, Klinika za dečju i preventivnu stomatologiju, Beograd, Srbija; \\ ¿Univerzitet u Beogradu, Institut za nuklearne nauke „Vinča“, Laboratorija za atomsku fiziku, Beograd, Srbija; \\ 3Univerzitet u Beogradu, Institut za anatomiju, Medicinski fakultet, Laboratorija za antropologiju, Beograd, Srbija
}

\begin{abstract}
KRATAK SADRŽAJ
Matične ćelije su pokazale veliki potencijal za primenu u tkivnom inženjerstvu u in vitro uslovima, regenerativnoj medicini, lečenju matičnim ćelijama i farmaceutskoj primeni. Sve ove grane, posebno primena u kliničkim istraživanjima, zahtevaće kontrolisano stvaranje visokokvalitetnih ćelija. Tradicionalnim tehnikama izolovana je većina primarnih ćelijskih kultura i ćelijskih linija, i vremenom su one postale standardne tehnike za različite ćelijske analize. Ipak, ovi uslovi gajenja nisu u mogućnosti da imitiraju dinamične, trodimenzionalne uslove mikrosredine niše matičnih ćelija iz in vivo uslova. $U$ pokušaju da se obezbede navedeni uslovi i u in vitro uzgajanju ćelija, razvile su se trodimenzionalne tehnike gajenja ćelija. U ovom preglednom radu opisujemo prednosti novorazvijenih poroznih nosača ćelija, kao ključnih činilaca u imitaciji ćelijske niše koji obezbeđuju mehaničku potporu, omogućuju rast ćelija, regeneraciju i razvoj novih krvnih sudova, dok vremenom bivaju razgrađeni i zamenjeni novostvorenim tkivom. Dalje, tehnike dinamičnog gajenja ćelija su opisane kao vid novog načina gajenja ćelijskih kultura koji predstavlja i pravac naših budućih istraživanja. U tom smislu, razvijajući optimalan, dinamički model gajenja ćelija, biće moguće obezbediti nove ćelije i tkiva visokog kvaliteta za sva dalja klinička istraživanja.
\end{abstract}

Ključne reči: matične ćelije; tehnike gajenja; nosači; ALBO-OS; bioreaktor

\section{UVOD}

Matične ćelije (MĆ) imaju sposobnost samoobnavljanja i usmeravanja u pravcu zrelih tipova ćelija koje grade sva tkiva i organe ljudskog organizma. Postoje dve osnovne grupe MĆ definisane po poreklu i potentnosti - embrionalne matične ćelije i zrele, mezenhimalne matične ćelije [1]. Embrionalne matične ćelije (EMĆ) jesu pluripotentne, sa sposobnošću neograničenog samoobnavljanja i usmeravanja u pravcu svih tipova ćelija prisutnih u organizmu. Mezenhimalne matične ćelije (MMĆ) izolovane su iz zrelih tipova tkiva, kao što su koštana srž, masno tkivo i tkiva usne duplje. MMĆ su multipotentne ćelije koje mogu biti usmerene u ograničen broj ćelijskih tipova. Takođe, sposobnost samoobnavljanja i usmeravanja zavise od vrste tkiva iz kojih su izolovane i starosti davaoca tkiva. Prednosti MMĆ su laka dostupnost i to što njihova primena povlači manje etičkih pitanja $[2,3]$. MĆ su pokazale veliki potencijal za primenu u tkivnom inženjerstvu u in vitro uslovima, regenerativnoj medicini, lečenju matičnim ćelijama i farmaceutskoj primeni. Sve ove grane, posebno primena u kliničkim istraživanjima, zahtevaće kontrolisano stvaranje visokokvalitetnih ćelija [4].

\section{TRADICIONALNE TEHNIKE GAJENJA ĆELIJA}

MĆ se uzgajaju u vidu jednog sloja ćelija, u dve dimenzije (2-D), na plastičnim podlogama ploča i boca namenjenih uzgajanju ćelija. Gajenje ćelija u 2-D uslovima primenjeno je na većini primarnih ćelijskih kultura i ćelijskih linija, i standardizovano za različite analize, od izolacije i karakterizacije ćelija do istraživanja razvoja oboljenja i testiranja lekova [5]. Da bi se uzgajale na plastičnim podlogama, EMĆ se moraju zasejati na prethodno pripremljene površine kako bi se olakšalo vezivanje ćelija za podlogu. Gajenje EMĆ u 2-D uslovima poboljšano je primenom određenih hranljivih medijuma bez prisustva proteina životinjskog porekla i dodataka za poboljšanje vezivanja ćelija za podlogu. Međutim, ujednačeno umnožavanje EMĆ se i dalje teško postiže u 2-D uslovima usled zahtevnih, skupih metoda, koje zahtevaju veliki stepen stručnosti $[5,6]$. Primenom posebnih indukcionih medijuma EMĆ su usmerene ka ektodermalnoj, mezodermalnoj i endodermalnoj lozi. Važna prednost gajenja EMĆ u jednom sloju jeste kontrolisano usmeravanje ćelija koje omogućuje podjednaku izloženost ćelija medijumu. Ipak, ovakvo usmeravanje često za rezultat ima mešovitu populaciju zrelih ćelija $[4,5,7]$.

Za razliku od embrionalnih, MMĆ poseduju prirodnu sposobnost da se lepe za plastičnu i staklenu podlogu. Proteini životinjskog porekla nisu potrebni za podsticanje lepljenja ćelija za podlogu, ali se ćelije uglavnom uzgajaju u medijumu koji u sebi sadrži serum životinjskog porekla. Primena takvih medijuma može biti potencijalni izvor prenosivih patogena i ograničiti ponovljivost ogleda. U skorije vreme razvijeni su i medijumi za uzgajanje MMĆ bez prisustva proteina životinjskog porekla, što predstavlja neophodan uslov za buduću kliničku primenu MMĆ [8]. Pri gajenju MMĆ u 2-D uslovima javljaju se određena ograničenja. Ćelije gajene u jednom sloju zahtevaju redovno presađivanje kako bi se zadržala potentnost i sposobnost samoobnavljanja, što je veoma neisplativo u slučaju uzgajanja velikog broja ćelija. Neophodno je održavati podjednake uslove raspoređenosti, rasta i prikupljanja ćelija, posledično umanjiti mogućnost heteregenosti u kulturi i obezbediti visok prinos ćelija. Tokom uzgajanja javljaju se fenotipske promene i ćelije gube potencijal rasta i usmeravanja nakon određenog broja pasaža [9]. Uprkos ograničenjima, izlaganjem ćelija posebnim medijumima u 2-D uslovima, MMĆ su usmerene ka različitim tipovima specijalizovanih ćelija, uključujući hondrocite, osteocite, adipocite, kardiomiocite, glatke mišićne ćelije i hepatocite $[10,11]$. Procena stadijuma diferentovanosti ćelija se najčešće utvrđuje veličinom ispoljavanja gena specifičnih za određeni tip zrelih ćelija i kvalitativnim bojenjem depozita vanćelijskog matriksa (VĆM). Osnovni nedostatak usmeravanja ćelija u 2-D uslovima jeste izostanak stvaranja funkcionalno aktivnih ćelija. 
One često diferentuju u prekursorne ćelije, te postoji mogućnost da tokom vremena dediferentuju [4]. Pre kliničke primene neophodno je izvršiti izmene u protokolima za usmeravanje ćelija. Uopšteno, 2-D uslovi gajenja ćelija nisu u mogućnosti da imitiraju dinamičnu i specijalizovanu trodimenzionalnu (3-D) mikrosredinu niše u kojoj rastu MĆ u in vivo uslovima.

\section{TRODIMENZIONALNE TEHNIKE GAJENJA ĆELIJA}

U pokušaju stvaranja mikrosredine u kojoj se imitiraju biološki uslovi rasta MĆ u in vitro uslovima, razvijene su 3-D tehnike gajenja ćelija. Zajednički cilj ovih metoda jeste imitacija sastava VĆM i rigidnosti niše u in vitro uslovima. Izazov predstavlja optimizacija protokola zavisno od tipa ćelija i cilja analize [4]. Stoga, ravnomerno umnožavanje MĆ bez gubitka genetičke stabilnosti ili potencijala za usmeravanje ka specijalizovanim ćelijama se mora očuvati nezavisno od primenjene tehnike.

\section{Statična trodimenzionalna kultura}

\section{Sfere}

Sfere su jedan od osnovnih 3-D metoda gajenja ćelija i predstavljaju nakupine ćelija u kojima je omogućena međućelijska interakcija u odsustvu drugih faktora. Veliki broj različitih tipova ćelija ima sposobnost spontane agregacije kada se zaseju u suspenziji u pločama za gajenje ćelija sa niskim stepenom adhezije, u obliku viseće kapi ili u rotacionim bocama [7, 12]. MMĆ se uspešno održavaju i gaje u sferama, ispoljavajući povećanje klonalnog rasta i multipotentnosti i aktivaciju gena odgovornih za pluripotentnost. Međutim, kao i pri gajenju u 2-D uslovima, dugotrajno održanje MMĆ u sferama spontano dovodi do njihovog sazrevanja [12]. Osteogena i hondrogena diferencijacija je uspešnija kod MMĆ gajenih u 3-D sferama, u poređenju sa 2-D uslovima diferencijacije. Hondrogena diferencijacija se pokazala posebno efikasnom kada su se ćelije gajile u vidu velike nakupine ćelija ili u vidu sfera, u poređenju sa gajenjem ćelija u jednom sloju. Ipak, ovaj metod nije primenljiv za umnožavanje ćelija usled nemogućnosti kontrole veličine stvorene nakupine ćelija, što dovodi do prerastanja, odumiranja i zaustavljanja ćelijskog umnožavanja [13]. Zavisno od tkiva iz kojeg su ćelije izolovane, sfere se mogu sastojati od heterogene populacije ćelija, sa različitim potencijalom umnožavanja. Još važniji nedostatak jeste ograničen protok kiseonika i hranljivih materija u središtu sfere, što postepeno vodi u sredinu sa sniženim nivoom kiseonika i, na kraju, stvaranja nekrotičnog centra. Zbog navedenih nedostataka, sfere se više primenjuju pri izučavanju samih 3-D ćelijskih kultura, usmeravanja ka zrelim ćelijama i biologije tumora, pre nego za umnožavanje ćelija homogene populacije i stvaranja visokokvalitetnih i uniformnih ćelijskih kultura $[13,14]$.

\section{Nosači}

Različiti prirodni i veštački biokompatibilni i biorazgradivi materijali se primenjuju za imitaciju biohemijskih i biofizičkih svojstava MĆ niše koja podstiče umnožavanje i/ili usmeravanje ćelije. Prirodni biomatrijali (agaroza, fibronektin, hijaluronska kiselina, citosan) u in vitro uslovima često prenose biološke si- gnale ćelijama [15]. Kao rezultat, biomaterijali mogu podstaći održanje ćelija i usmeravanje. Međutim, problem kao što je raznolikost i mogućnost prenosa određenih bolesti preko materijala životinjskog porekla ograničavaju njihovu primenu [15, 16]. Sintetski polimeri (polietilen glikol, polilizin, polilaktična kiselina, poliglikolna kiselina, polilaktid-koglikolna kiselina) predstavljaju grupu veštački napravljenih nosača različitih mehaničkih svojstava (veličina pora, elastičnost, adhezija, zatezna čvrstoća) [17-22]. Biorazgradivi, porozni nosači ćelija predstavljaju ključne činioce u imitaciji ćelijske niše koji obezbeđuju mehaničku potporu, omogućuju rast ćelija, regeneraciju i razvoj novih krvnih sudova, dok vremenom bivaju razgrađeni i zamenjeni novostvorenim tkivom $[23,24,25]$. Inovativni nosač napravljen od keramičkog dela koji imitira koštanu strukturu i tankog sloja polimera preko, koji doprinosi boljim mehaničkim svojstvima i biokompatibilnosti, pokazao se kao veoma dobar biomaterijal namenjen primeni u koštanoj regeneraciji (Slika 1) $[21,25,26]$. Nosači se često primenjuju za imitaciju VĆM, podstiču umnožavanje, migraciju i sazrevanje MĆ. Mogu biti napravljeni od biomaterijala, nakon čega se ćelije zasejavaju, migriraju i zatim se umnožavaju u samom nosaču [20, 27, 28]. Takvi nosači u sebi mogu sadržati faktore rasta i citokine i obezbediti mehaničku stimulaciju za usmeravanje MĆ. $S$ druge strane, u nosače se mogu ugraditi inkapsulirane ćelije u vreme njihovog pravljenja. Napravljeni nosači se često primenjuju za zasejavanje MĆ pre njihovog usmeravanja i primene u tkivnom inženjerstvu [28]. Nedavno smo objavili uspešnu primenu kompozitnog nosača, koji predstavlja kombinaciju kalcijum-hidroksiapatita i polilaktid-koglikolne kiseline, pod imenom ALBO-OS, kao koštanog zamenika [21,25]. Nosač velike mikro i nanoporoznosti pokazao se kao veoma pogodan za ćelijsku adheziju i umnožavanje (Slika 2), obezbeđujući veliku površinu, bolju adheziju i veći prostor za usmeravanje MMĆ [24]. Nadalje, pokazano je stvaranje novog mineralizovanog matriksa, osteokonduktivno i određeno osteoinduktivno dejstvo na ćelije (Slika 3). U in vivo uslovima se pokazalo da ALBO-OS ima zadovoljavajuću zateznu čvrstoću i pruža dobru mehaničku potporu tokom čitavog perioda stvaranja nove kosti [21, 24, 25].

Pokazano je da mehanička svojstva nosača podstiču usmeravanje MMĆ ka različitim ćelijskim tipovima. Mekši supstrati podstiču MMĆ da diferentuju ka neuralnim i beta ćelijama, hondrocitima i adipocitima. $S$ druge strane, povećanje rigidnosti podstiče usmeravanje ka mioblastima i osteoblastima. Studija u kojoj je nosač prenosio mehanički stres na MMĆ silama pritiska koje imitiraju pokret zgloba pokazala je uticaj nosača na povećanje ispoljavanja gena odgovornih za hondrogenu diferencijaciju [27,28]. Pošto sastav i mehanička svojstva biomaterijala vode MMĆ da diferentuju u posebne ćelijske tipove, važno je da budu dobro definisani i da se mogu jednostavno proizvesti. Interakcija između ćelija i ćelija i VĆM u statičnoj 3-D kulturi tokom održanja i umnožavanja MMĆ može omogućiti uvid u osnovnu biologiju ćelijskih procesa i mehanizama. Glavni izazov statične 3-D kulture ostaje umnožavanje velikog broja ćelija $\mathrm{u}$ individualnom nosaču. Kako se nosač uvećava, rast ćelija u njegovom centru može biti ugrožen na sličan način, kao što je to slučaj u sferama. Protok kiseonika, hranljivih materija i produkata metabolizma u čitavom prostoru nosača može biti ograničen [4]. Metode koje mogu omogućiti rast ćelija u 3-D uslovima bez nutritivnih nedostataka predstavljaju predmet trenutnih istraživanja. 


\section{Dinamična trodimenzionalna kultura}

Bioreaktori omogućuju odvijanje, nadzor i kontrolu bioloških procesa. U tkivnom inženjerstvu omogućavaju uzgajanje velike gustine ćelija, rast i umnožavanje ćelija i umanjuju raznolikost prisutnu u statičnim uslovima uzgajanja ćelija. Novi način uzgajanja ćelija traži definisane i dobro kontrolisane uslove temperature, koncentracije kiseonika i hranljivih materija, pH sredine, kao i uklanjanje produkata metabolizma. Različite vrste 3-D tehnika uzgajanja ćelija obezbeđuju dobro umnožavanje i usmeravanje MĆ ka zrelim ćelijama [29]. Različite tehnike koje su primenjene u razvoju sistema bioreaktora određuju njihovu namenu.

U proteklih nekoliko godina razvijeno je više tipova bioreaktora namenjenih umnožavanju i vođenoj diferencijaciji od pojedinačne ćelije do uzgajanja tkiva. Rotirajuće boce za gajenje ćelija su najjednostavniji i najpraktičniji sistem bioreaktora. Lokalne hidrodinamske sile predstavljaju osnovu sistema i na ćelije deluju silama smicanja. U središtu sistema se nalazi nosač sa ćelijama, dok magnetna mešalica omogućuje stalni protok medijuma oko nosača. Sistem je smešten u inkubatoru sa kontrolisanim uslovima sredine. Vrednost sila smicanja definisana je brzinom mešanja medijuma. Nedostaci ove metode sadržani su u mogućnosti stvaranja gustog sloja ćelija na površini, koje mogu ugroziti ishranu ćelija u dubljim strukturama nosača, kao i stvaranja nejednakih sila smicanja, uz najveće vrednosti na dnu boce u kojoj se ćelije gaje [30]. Iz potrebe za boljom kontrolom sila smicanja osmišljeni su rotirajući bioreaktori sa horizontalnom rotacijom i simulacijom mikrogravitacije. $\mathrm{Na}$ ovaj način ograničenja vezana za jednak protok hranljivih materija i produkata metabolizma su smanjena [31]. Kada su se uvideli nedostaci vezani za sisteme zasnovane na rotaciji, došlo je do razvoja bioreaktora sa perfuzijom. Sistemi sa perfuzijom omogućuju stalnu razmenu hranljivih materija i produkata me- tabolizma, što omogućuje bolju kontrolu parametara za gajenje ćelija. Prenos hranljivih materija i kiseonika se odvija kroz čitav nosač, dok se medijum u sistemu menja u redovnim intervalima [32]. Na kraju, bioreaktori sa dejstvom mehaničkih sila su osmišljeni kako bi se imitirala fiziologija tkiva, primenjujući direktne mehaničke sile zatezanja i pritiska. Mehanička stimulacija može biti u vidu savijanja, istezanja, skupljanja i pritiska. Pokazano je da direktna mehanička stimulacija podstiče umnožavanje ćelija, njihovu osteogenu diferencijaciju i stvaranje mineralizovanog VĆM. Potencijalni nedostatak može predstavljati ograničenje u protoku medijuma kod većih nosača [33].

Buduća prospektivna istraživanja bi trebalo da uključe gajenje MMĆ na poroznim nosačima kao najpogodnijim strukturama za umnožavanje i usmeravanje ćelija u dinamičnim sistemima, kao što je bioreaktor sa perfuzijom, kako bi se omogućili homogeni uslovi gajenja. U tom smislu, biće omogućen razvoj visokokvalitetnih novih ćelija i tkiva nezavisno od veličine nosača, što predstavlja kvalitetnu osnovu za sva buduća klinička istraživanja.

\section{ZAKLJUČAK}

Primena matičnih ćelija u biomedicini zahteva gajenje velikog broja uniformnih ćelija, koji premašuje milione ćelija koje je danas moguće gajiti tradicionalnim tehnikama. Nedavne studije su pokazale da transplantacija velikog broja ćelija daje bolji ishod lečenja. Kliničke studije koje će uključiti ćelijsku terapiju će zahtevati milijarde i trilione novih ćelija. Napredak u primeni medijuma bez proteina životinjskog porekla, tehnikama uzgajanja i opremi su od velike važnosti. Gajenje velikog broja ćelija zahteva saradnju istraživača iz oblasti biomedicine i inženjerstva, kako bi se razvio optimalni dinamični metod gajenja ćelija koji će omogućiti sprovođenje ćelijske terapije. 